\title{
ТУРБИДИТНЫЕ РЕЗЕРВУАРЫ СЕВЕРНОГО САХАЛИНА И ЕГО ШЕЛЬФА: РАСПРОСТРАНЕНИЕ И ПЕРСПЕКТИВЫ НЕФТЕГАЗОНОСНОСТИ
}

Ткачева Н.А. *, Кругляк В.Ф. *, Коблов Э.Г. ** (ЗАО «Сахалинские Проекты», ООО «СахНИПИморнефть)

Нефтегазопоисковые работы на Северном Сахалине имеют длительную ксторию: с 20-х годов прошлого столетия на суше острова (открыто 61 месторождение нефти и газа) и с середины 70-x r.r. на его шельфе (открыто 9 месторождений). Основными промышленно нефтегазоносными являются отложения трех стратиграфических горизонтов: дагинского (нижний-средний миоцен), окобыкайского (средний мноцен) и нижненутовского (верхний миоцен). Залежи связаны с коллекторами порового типа: песчаноалевритовыми пластами в толшах переслаивания песчано-алевритовьх и глинистых пород.

Подавляющее большинство залежей на месторождениях Северного Сахалина приурочено к пластам резервуарам, формировавшимся в обстановках пельфа и прибрежной низменности. Наблюдаемые и предполагаемые литологические ловушки связывались с обычными седиментитами в различных видах песчаных резервуаров-ловушек: барами, береговыми валами, руслами дельтовыми притоками.

Открытие месторождений Одоптинской группы и их изучение сейсморазведкой 3D (Одопту-море, Пильтун-Астохское, Аркутун-Дагинское) показало, пто залежи нижней половины продуктивного нижненутовского подгоризонта приурочены к песчаным резервуарам, образованным гравитационным перемещением по материковому склону (турбидитные резервуары). Данные сейсморазведки 2D и 3D более позднего периода исследований говорят о широком, а для ряда районов преобладающем, распространении турбидитных резервуаров в разрезе как Северного Сахалина, так и, особенно, его шельфа. Пространственное распределение таких резервуаров определяется положением материкового склона и дельтовой системы Палео-Амура на разных стадиях осадконакопления

Имеюшиеся материалы сейсморазведки и глубокого бурения позволяют выделить две крупные зоны (пояса) распространения турбидитных резервуаров: внешний и внутренний. Внешний пояс турбидитных резервуаров занимает зону современного внешнего шельфа (глубины моря 100-200м), протягивается вдоль Северо-Восточного Сахалина и расположен в пределах западного борта Дерюгинского бассейна. Здесь по данным сейсморазведки намечается несколько обширных полей распространения турбидитньх резервуаров: Ceверо-Шмидтовское, Восточно-Шмидтовское и Восточно-Одоптинское.

В пределах Северо-Сахалинского бассейна расположен внутренний пояс турбидитных резервуаров, который протягивается полосой шириной $35-50 \kappa м$ вдоль северо-восточного побережья Сахалина от зал. Чайво до п-ова Шмидта, занимая прибрежную часть острова и мелководную зону шельфа. Еще один сегмент этого пояса расположен к северу и северо-западу от полуострова Шмидта.

В северном сегменте (Шмидтовский район) внутреннего пояса основные направления работ связываются с поисками залежей нефти и газа в миоценплиоценовых отложениях двух типов ловушек: структурных и литолого-стратиграфических. Первые приурочены $\mathrm{K}$ антиклинальным структурам СевероШмидтовской складчато-сдвиговой зоны и других тек- тонических структур и группируются в структурные зоны нефтегазонакопления: Астрахановскую, СевероЭспенбергскую, Эспенб́ерпскую, СевероШмидтовскую, Елизаветинскую, Шмидтовскую. Площади ловушек по имеющимся материалам оцениваются от 30 до $300 \mathrm{kм}^{2}$. Основные перспективные горизонты: дагинский и нижненутовский. Перспективны также палеогеновые отложения и фундамент. Вторая группа ловушек представлена крупными литологическими ловушками с элементами стратиграфического и тектонического (дизъюнктивного) экранирования в отложениях нутовско-окобыкайского комплекса и базальных слоев помырского горизонта. Ловушки отличаются крупными размерами $\left(80-600 \mathrm{kм}^{2}\right)$ и приурочены к Приамурской моноклинальной зоне, Западно-Охотскому разлому и северному периклинальному погружению Северо-Шмидтовской складчато-сдвиговой зоны

Перспективнымв объектами центрального и южного сегментов являются структурнолитологические и литологические ловушки и зоны ловушек Северо-Восточного Сахалина и его шельфа: Пильско - Северо - Колендинская, СевероОдоптинская, Западно-Одоптинская, Южно-АйяшскоУльвинская и Северо-Венинская. Площади ловушек от 30 до $400 \mathrm{KM}^{2}$.

Основные перспективы поксков крупных месторождений нефти и газа в ловушках внешнего пояса связаны с турбидитньми резервуарами миоценплиоценового комплекса на присахалинском борту Дерюгинского бассейна. Полоса распространения установленньх и предполагаемых литологостратиграфкческих и структурно-литологических ловушек в этих отложениях по данным сейсморазведки протягивается в пределах Восточно-Сахалинской моноклинальной зоны на $350 \mathrm{~km}$ вдоль ЗападноОхотского разлома и восточного крыла ШІмндтовского поднятия от Ионинского поднятия на севере до южного окончания Восточно-Одоптинской антиклинальной зоны на юге. Площади таких ловушек - 300-400км².

Нефтегазовый потенциал направления нефтегазопоисковых работ, связанного с турбидитными резервуарами оценивается очень высоко. Перспективные выявленные и предполагаемые ловушки являются одним из главных резервов увеличения нефтегазодобычи в бассейне, в том числе и за сдет освоения мелководной зоны наклонно-направленным бурением. 